\title{
Water conductivity of arctic zone soils (Spitsbergen)**
}

\author{
Barbara Witkowska-Walczak ${ }^{1 *}$, Cezary Stawiński ${ }^{1}$, Piotr Bartmiński ${ }^{2}$, Jerzy Melke $^{2}$, \\ and Jacek Cymerman ${ }^{3}$
}

\author{
${ }^{1}$ Institute of Agrophysics, Polish Academy of Sciences, Doświadczalna 4, 20-290 Lublin, Poland \\ ${ }^{2}$ Department of Soil Science and Soil Protection, Maria Curie-Skłodowska University, Al. Kraśnicka 2cd, 20-718 Lublin, Poland \\ ${ }^{3}$ State School of Higher Education, Pocztowa 54, 22-100 Chełm, Poland
}

Received January 15, 2014; accepted June 27, 2014

\begin{abstract}
A b s t r a c t. The water conductivity of arctic zone soils derived in different micro-relief forms was determined. The greatest water conductivity at the $0-5 \mathrm{~cm}$ depth for the higher values of water potentials $\left(>-7 \mathrm{~kJ} \mathrm{~m}^{-3}\right)$ was shown by tundra polygons (Brunic-Turbic Cryosol, Arenic) - 904-0.09 $\mathrm{cm} \mathrm{day}^{-1}$, whereas the lowest were exhibited by Turbic Cryosols $-95-0.05 \mathrm{~cm}_{\text {day }}{ }^{-1}$. Between -16 and $-100 \mathrm{~kJ} \mathrm{~m}^{-3}$, the water conductivity for tundra polygons rapidly decreased to $0.0001 \mathrm{~cm} \mathrm{day}^{-1}$, whereas their decrease for the other forms was much lower and in consequence the values were $0.007,0.04$, and $0.01 \mathrm{~cm} \mathrm{day}^{-1}$ for the mud boils (Turbic Cryosol (Siltic, Skeletic)), cell forms (Turbic Cryosol (Siltic, Skeletic)), and sorted circles (Turbic Cryosol (Skeletic)), respectively. In the 10-15 cm layer, the shape of water conductivity curves for the higher values of water potentials is nearly the same as for the upper layer. Similarly, the water conductivity is the highest $-0.2 \mathrm{~cm}^{-1} \mathrm{y}^{-1}$ for tundra polygons. For the lower water potentials, the differences in water conductivity increase to the decrease of soil water potential. At the lowest potential the water conductivity is the highest for sorted circles $-0.02 \mathrm{~cm} \mathrm{day}^{-1}$ and the lowest in tundra polygons $-0.00002 \mathrm{~cm}$ day $^{-1}$.

$\mathrm{K}$ e y w o r d s: soils, arctic zone, water conductivity, grain size distribution, pore size distribution
\end{abstract}

\section{INTRODUCTION}

Water retention and conductivity in both saturated and unsaturated zones determine soil water balance. Moisture conditions in soils exert a decisive influence on their thermal and mechanical properties that influence the temperature in the soil profile. Knowledge of the hydrophysical properties

\footnotetext{
*Corresponding author e-mail: bwitwal@ipan.lublin.pl

**This work has been partly financed from the funds of the National Centre of Research and Development in the frame of the project: Knowledge Hub FACC JPI/06/2012 'Modelling European Agriculture with Climate Change for Food Security' MACSUR, P139.
}

is necessary for interpretation and forecasting of practically all physical, chemical, and biological processes that occur in soils, since modelling of these processes requires representative data on soil hydrophysical characteristics (Novak, 2011; Shein and Gonczarow, 2007; Sławiński et al., 2004; Świtoniak et al., 2014; Zadeh and Bayat, 2012).

The recent climate change started in the 19th century. Actually, the estimation of the initial period is a matter of general agreement and it is not strictly equal to local or regional observations. The observed warming has been greater over land than that over oceans. Since continents occupy larger areas on the northern hemisphere, there was a tendency for a higher temperature rise in the northern than in the southern hemisphere. Values of the average temperature rise also differ in accordance with differences in the climate of various regions. The rise is very small in the equatorial regions and it increases with latitude, both north and south. For example, in Central Europe, the average temperature increased between $1.1-1.3^{\circ} \mathrm{C}$, whereas within the Arctic Circle at latitudes between 70 and $90^{\circ}$, the average rise was $2.1^{\circ} \mathrm{C}$ during $1880-2004$. The rise of the average temperature, especially in the arctic zone and specific periglacial conditions, initiated many scientific investigations in this terrain (Chojnicki, 2013; Kutilek and Nielsen, 2010; Migała et al., 2014; Paltineau et al., 2012; 2007; Zagórski et al., 2012).

The main processes in the polar zone are cryogenic, ie frozen segregation processes, swelling, shrinking and cracking, cryostatic stresses, frozen and gravitational slope movements. Consequently, there is a diversity of microrelief surface forms as a result of the above-mentioned processes and varied grain size distribution and water

(C) 2014 Institute of Agrophysics, Polish Academy of Sciences 
properties. The good conditions for biosphere development triggered soil-forming processes, especially on flat surfaces with low inclination (Angiel, 1994; Bockheim, 1980; Tedrow, 1977; Trenberth et al., 2007; Washburn, 1980).

The mechanisms of mass and energy transport in soil include molecular liquid diffusion, molecular vapour diffusion, capillary flow, convective transport, evaporation-condensation processes together with latent heat flow, pure hydrodynamic flow, and movement due to gravity. It is necessary to mention freezing-thawing processes, which are modifying water transport through soil profile (Hillel, 1998; Kabala and Zapart, 2012; Lal and Shukla, 2004; van Genuchten and Pachepsky, 2011).

The mass flux is affected by the temperature and temperature gradient due to temperature dependence of bound water properties, as well as by the complicated pore network, which is difficult to describe in a given soil. A dominant mechanism under a specific set of conditions in a particular material often does not exist and it is more likely that the mass and energy transport results from a combination of mechanisms. The properties of the soil matrix, such as the bulk density of the solid phase, grain size distribution, and mineralogical and aggregate composition determine soil resistance for water accumulation and transport in different directions (Kirkham, 20014; Kutilek, 2011; Sławiński, 2003; Sławiński et al., 2004; WitkowskaWalczak and Sławiński, 2005).

The relationship between the water conductivity coefficient and soil water potential or water content is a basic characteristic determining water movement in soil. Its value at the particular soil water potential has an important significance in the course of different soil processes. This relationship is necessary for description of water movement, prediction of water content distribution in soil profile, making soil melioration, and modelling other soil properties (Shein and Gonczarov, 2007; Sławiński, 2003; van Genuchten and Pachepsky, 2011; Witkowska-Walczak et al., 2012).

Theories of water flow are based on empirically derived transport equations and well-established physical principles. Hydrodynamic approaches have been used to describe liquid flow for cases in which salt and temperature effects are not significant factors. When salts are a contributing factor, diffusion and dispersion mechanisms must be incorporated into the theory and the concepts of electrostatics and electrokinetics are applicable and useful. For flow systems in which temperature and salt concentrations are variable, a theory for the thermodynamics of irreversible processes has been applied to soil water flow (Sławiński et al., 2004; van Genuchten and Pachepsky, 2011; Youngs, 2008).

The climate change effects strongly affect not only on the micro-relief creation but also the hydrophysical properties of arctic initial soils. It was shown for water retention in our earlier paper (Melke et al., 2013).
Therefore, the aim of this paper was to determine the water conductivity of arctic soils derived in different micro-relief forms of Spitsbergen (Svalbard Archipelago, North Sea).

\section{MATERIAL AND METHODS}

The investigation site was the Svalbard Archipelago and its largest island - Spitsbergen. The island is characterized by a gentle climate, and the recent rise of air temperature is the cause of glacier thawing. The area of research covers the NW part of Wedel Jarlsberg Land $\left(77^{\circ} 26^{\prime}-77^{\circ} 35^{\prime} \mathrm{N}\right.$ and $\left.13^{\circ} 55^{\prime}-14^{\circ} 54^{\prime} \mathrm{E}\right)$. The whole area is divided by lines of mountain ridges, between which there are valleys widening towards the sea, creating a vast plain in the form of marine terraces in its proximity. Water movement was determined for the soils formed on four characteristic micro-relief surface forms (Fig.1) (Fischer and Skiba, 1993, Tedrow, 1977; Washburn, 1980; Kirkham, 2014; Klimowicz et al., 2013): - Mud boils are circular and inconsiderable raised forms with a diameter between 50 and $70 \mathrm{~cm}$. Very poor vegetation and their light grey colour, which can be seen from a long distance, make an impression of 'spots'. Therefore larger surfaces of mud boils are often called the 'spotted' tundra or 'spotted' soils.

- Cell forms are flat 4-6-sided polygons with a diameter between 50 and $100 \mathrm{~cm}$. They are neighbours of mud boils and sorted circles, but not so frequently. In the cracks around these forms, fine rock material can be observed. It is usually submerged in detritus-soil material under the terrain surface. The shallow ground water level and anaerobic conditions promote gleyic processes.

- Sorted circles are very expressive forms in the landscape, especially these above the terrain surface. They are circular or elongated ramparts with a diameter between 100 and $300 \mathrm{~cm}$. Their height is varied, some of them are flat, and others can be located below the terrain surface.

- Tundra polygons are large surface forms. Their diameters are usually between several to dozen meters. They are shown by lines of ice wedges (or soil wedges) in which mineral and organic material is located. They are frequent forms in some surfaces of lower sea terraces.

The experimental fields were located within the microrelief forms described above. Soil pits were made and profiles were described according to the WRB classification system (Jahn et al., 2006). The soil profiles represented the following groups according to the WRB (IUSS Working Group, 2007):

- Turbic Cryosols (Skeletic) in sorted circles,

- Turbic Cryosols (Siltic, Skeletic) in mud boils,

- Turbic Cryosols (Siltic, Skeletic) in cell forms,

- Brunic* Turbic Cryosols (Arenic) in tundra polygons (Prefix 'brunic' in the last case is not listed as a possible qualifier for Cryosols. However, it was used because the soils meet the referring criteria). 

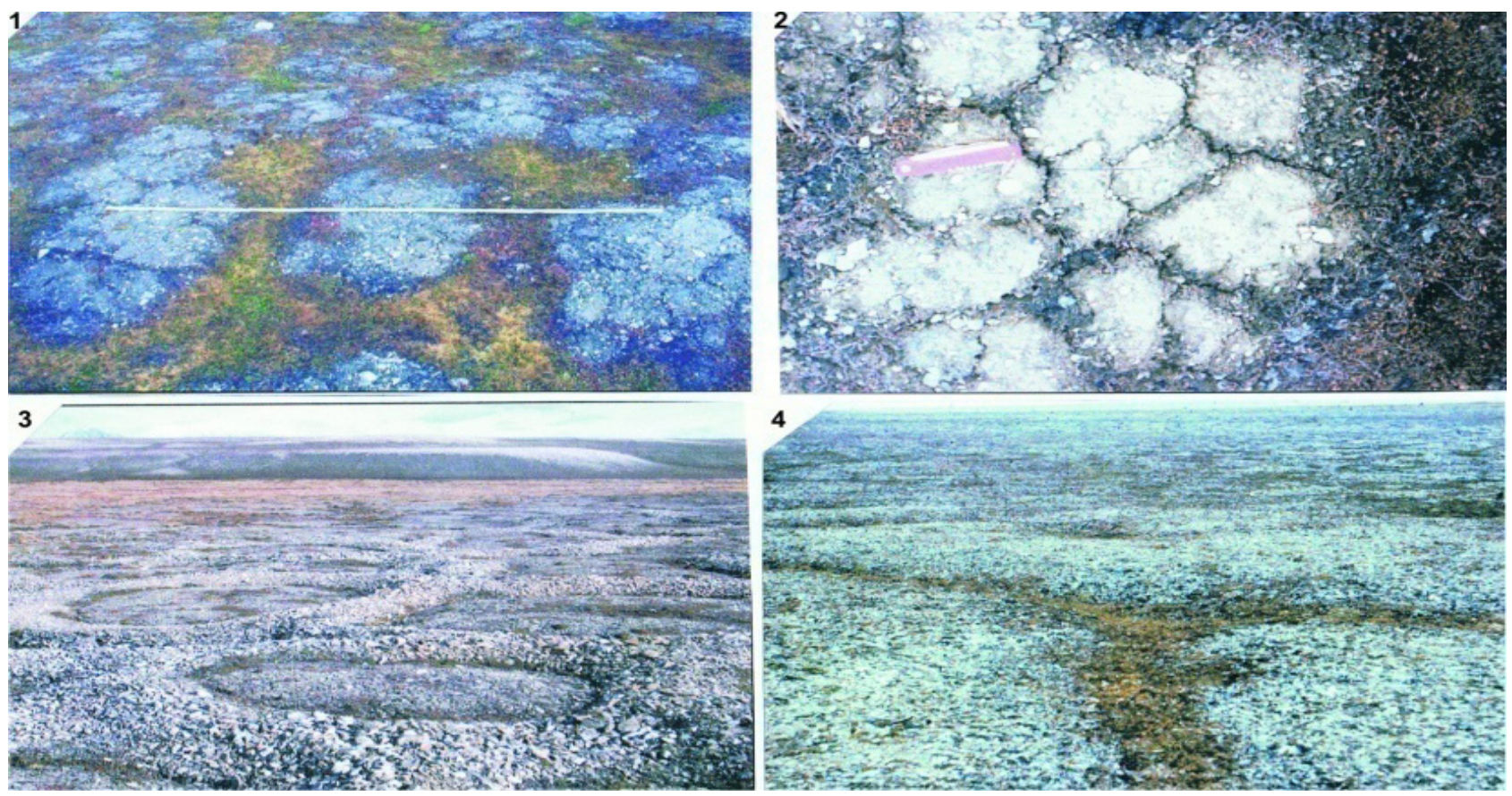

Fig. 1. Micro-relief surface forms: 1 - mud boils; 2 - cell forms; 3 - sorted circles; 4 - tundra polygons (Klimowicz et al., 2013).

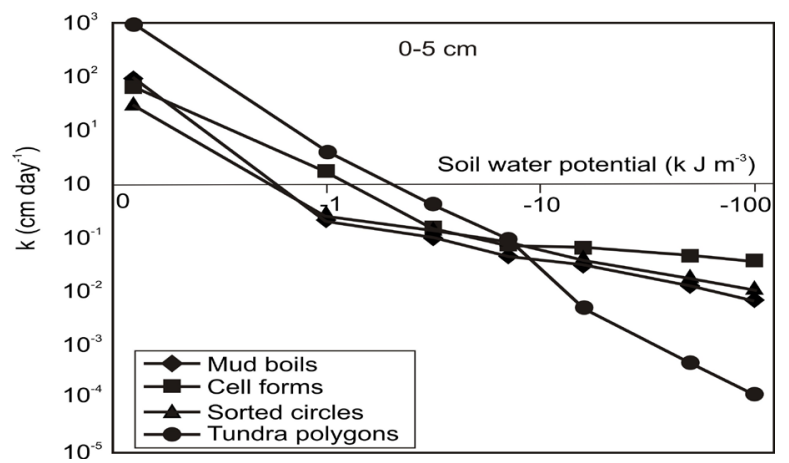

$\mathrm{b}$

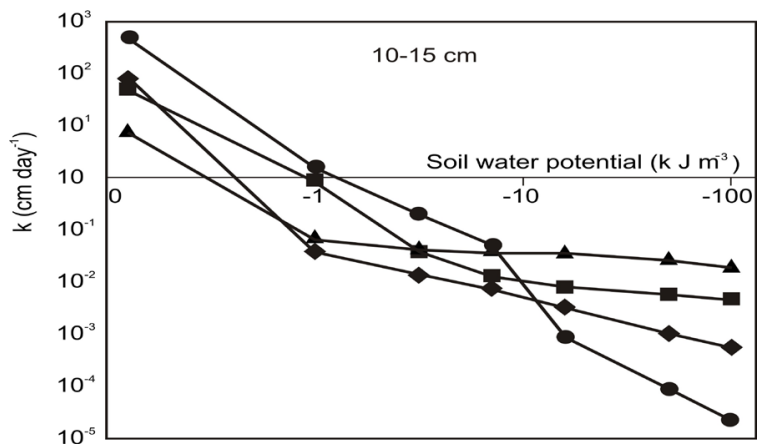

Fig. 2. Relationship between soil water potential and water conductivity coefficient for the investigated polar micro-relief forms: $\mathrm{a}-0-5 \mathrm{~cm}$ and $\mathrm{b}-10-15 \mathrm{~cm}$ layers.

The soil properties were measured on samples collected from the experimental fields in a disturbed and undisturbed state (in soil cores, $\mathrm{h}=5 \mathrm{~cm}$, dia $=5 \mathrm{~cm}$ ) in five replications from two depths ie $0-5$ and $10-15 \mathrm{~cm}$. The total grain size distribution was determined by the standard sieve method and the primary grain size distribution using the laser diffraction method (Ryżak and Bieganowski, 2013), bulk density - by the standard gravimetric method (drying in $105^{\circ} \mathrm{C}$ ), specific density - by the standard method in a pycnometer, whereas total porosity was calculated on the basis of bulk and specific densities. The specific surface area of soils was determined using adsorption/desorption isoterms of water vapour at $\mathrm{p} / \mathrm{p} 0$ between 0 and 1 at $20 \mathrm{oC}$ in a Dynamic VaporSorption-Intrinsic device (Surface Measurement Systems Ltd., UK). The quantity of different size pores was calculated on the basis of water retention curves (Melke et al., 2013).
Measurement of water conductivity in a saturated zone was carried out by means of a device produced by EijkelkampAgrisearch Equipment, Wageningen, the Netherlands, using the constant head standard method (Fig. 2).Water conductivity in an unsaturated zone was determined using a laboratory TDR (Time Domain Reflectometry) test measuring moisture, soil water potential, temperature and salinity using the instantaneous profile method (IPM) (Sławiński, 2003; Sławiński et al., 2002, 2006; Sobczuk et al., 1992). Water conductivity was measured within the range from -0.1 to $-100 \mathrm{~kJ} \mathrm{~m}^{-3}$, which is limited by the tensiometer measurement range. The calculations of water conductivity were made for the following values of soil water potentials: $-0.1,-1,-3.1,-7,-16,-50$ and $-100 \mathrm{~kJ} \mathrm{~m}^{-3}$. The soil water dynamic properties were measured in five replications. All statistical calculations were made by the 
STATISTICA program (SAS, 1989). The tables and figures show mean values. Relative standard deviations did not exceed 4\% (Sławiński et al., 2004, 2006).

\section{RESULTS AND DISCUSSION}

The relationship between soil water potential $(\Psi)$ and water conductivity $(\mathrm{k})$ for the investigated polar soils derived on the different micro-relief forms is presented in Fig. 2. It can be seen from the data in Fig. 2 that the greatest water conductivity at the $0-5 \mathrm{~cm}$ depth for the higher values of water potentials $\left(-0.1\right.$ to $\left.-7 \mathrm{~kJ} \mathrm{~m}^{-3}\right)$ is shown by the tundra polygons ranging from -904 to $0.09 \mathrm{~cm} \mathrm{day}^{-1}$, next the mud boils -95 to $0.05 \mathrm{~cm} \mathrm{day}^{-1}$, and cell forms $-65.5-0.08 \mathrm{~cm}$ day $^{-1}$, whereas the values are the lowest for the sorted circles was $32-0.09 \mathrm{~cm} \mathrm{day}^{-1}$. For the lower water potentials (-7 to $-16 \mathrm{~kJ} \mathrm{~m}^{-3}$ ), water conductivity was nearly the same for all micro-relief forms at $-7 \mathrm{~kJ} \mathrm{~m}^{-3}$ and varied from $0.09 \mathrm{~cm}^{\text {day }}{ }^{-1}$ for the tundra polygons to $0.05 \mathrm{~cm} \mathrm{day}^{-1}$ for the mud boils. At $-16 \mathrm{~kJ} \mathrm{~m}^{-3}$, water conductivity is slightly lower for the cell forms, sorted circles and mud boils, 0.07, 0.04 and $0.03 \mathrm{~cm}$ day $^{-1}$, respectively, and much lower for the tundra polygons $0.005 \mathrm{~cm}^{-1 a y}{ }^{-1}$. Between -16 and $-100 \mathrm{~kJ} \mathrm{~m}^{-3}$, the values of water conductivity for the tundra polygons rapidly decreased to $0.0001 \mathrm{~cm} \mathrm{day}^{-1}$, whereas their decrease for the other forms was much lower and, in consequence, they are $0.007,0.04$, and $0.01 \mathrm{~cm} \mathrm{day}^{-1}$ for the mud boils, cell forms and sorted circles, respectively.

In the 10-15 cm layer for the higher values of water potentials $\left(-0.1\right.$ to $\left.-7 \mathrm{~kJ} \mathrm{~m}^{-3}\right)$, the shape of water conductivity curves is nearly the same as for the upper soil layer. The only difference is that water conductivity is more diversified from $-3.1 \mathrm{~kJ} \mathrm{~m}^{-3}$. They vary between $0.05 \mathrm{~cm}^{\text {day }}{ }^{-1}$ for the sorted circles to $0.01 \mathrm{~cm}^{\text {day }}{ }^{-1}$ for the mud boils. Likewise in the upper layer, water conductivity is the highest $0.2 \mathrm{~cm} \mathrm{day}^{-1}$ for the tundra polygons. For the lower water potentials $\left(-100\right.$ to $\left.-7 \mathrm{~kJ} \mathrm{~m}^{-3}\right)$, the differences in water conductivity increase to the decrease of soil water potential. Finally water conductivity is the highest for the sorted circles $0.02 \mathrm{~cm} \mathrm{day}^{-1}$, and next for: the cell forms, mud boils $-0.005,0.0006 \mathrm{~cm} \mathrm{day}^{-1}$, respectively, whereas it is the lowest $0.00002 \mathrm{~cm}$ day $^{-1}$ in tundra polygons.

In the analysis of the dynamic water characteristics of the investigated soils derived on different polar micro-relief forms, the main problem is to connect them to the other physical properties ie structure and bulk density, porosity, specific surface area, grain soil distribution (texture), and pore size distribution. Some of them are presented in Table 1. It can be seen in Table 1 that the lowest bulk densities characterize the tundra polygons -1.26 and $1.18 \mathrm{~g} \mathrm{~cm}^{-3}$, whereas the highest - the sorted circles -1.88 and $1.94 \mathrm{~g} \mathrm{~cm}^{-3}$ respectively, for both layers $(0-5$ and $10-15 \mathrm{~cm})$. The mud boils and cell forms have the mean values of bulk density of 1.521.57 , and $1.68-1.76 \mathrm{~g} \mathrm{~cm}^{-3}$, respectively. Therefore, the differences between the layers are no higher than $0.08 \mathrm{~g} \mathrm{~cm}^{-3}$. Calculated total porosity (from specific $\left(2.65 \mathrm{~g} \mathrm{~cm}^{-3}\right)$ and bulk densities) is the highest in the tundra polygons 52.4 and $55.5 \%$ and the lowest in the sorted circles 26.2 and $28.8 \%$, respectively, for both layers $(0-5$ and $10-15 \mathrm{~cm})$. The mud boils and cell forms have the mean values of calculated total porosity of $42.2-40.7$, and $36.4-33.6 \%$, respectively. Active porosity (not closed pores), ie the number of pores in which the water can be retained or moved were lower than calculated porosity not more than $7.3 \%$ (for the tundra

T a b l e 1. Properties of investigated soils

\begin{tabular}{|c|c|c|c|c|c|}
\hline Micro-relief forms & $\begin{array}{l}\text { Bulk density } \\
\qquad\left(\mathrm{g} \mathrm{cm}^{-3}\right)\end{array}$ & $\begin{array}{l}\text { Total porosity } \\
\left(\mathrm{P}_{\mathrm{t}}\right)(\%) \\
\text { (calculated) }\end{array}$ & $\begin{array}{l}\text { Active porosity } \\
\qquad\left(\mathrm{P}_{\mathrm{act}}\right)(\%)\end{array}$ & $\begin{array}{c}\text { Differences } \\
\text { between } \mathrm{P}_{\mathrm{t}} \text { and } \mathrm{P}_{\text {act }} \\
(\%)\end{array}$ & $\begin{array}{l}\text { Specific surface } \\
\text { area }\left(\mathrm{m}^{2} \mathrm{~g}^{-1}\right)\end{array}$ \\
\hline \multicolumn{6}{|c|}{$0-5 \mathrm{~cm}$} \\
\hline Mud boils & 1.52 & 42.2 & 39.3 & 2.9 & 26 \\
\hline Cell forms & 1.68 & 36.4 & 35.0 & 1.4 & 13 \\
\hline Sorted circles & 1.88 & 28.8 & 24.9 & 3.9 & 8 \\
\hline Tundra polygons & 1.26 & 52.4 & 48.9 & 3.5 & 21 \\
\hline
\end{tabular}

$10-15 \mathrm{~cm}$

\begin{tabular}{|c|c|c|c|c|c|}
\hline Mud boils & 1.57 & 40.7 & 36.4 & 4.3 & 29 \\
\hline Cell forms & 1.76 & 33.6 & 33.4 & 0.2 & 11 \\
\hline Sorted circles & 1.94 & 26.2 & 23.6 & 2.6 & 8 \\
\hline Tundra polygons & 1.18 & 55.5 & 48.2 & 7.3 & 26 \\
\hline
\end{tabular}


polygons $10-15 \mathrm{~cm}$ ) and not less than $0.2 \%$ (for the cell forms $10-15 \mathrm{~cm}$ ). Specific surface area (measured using vapour water) has the highest values in the mud boils for both layers 26 and $29 \mathrm{~m}^{2} \mathrm{~g}^{-1}$ and lower in tundra polygons 21 and $26 \mathrm{~m}^{2} \mathrm{~g}^{-1}$, respectively. The cell forms have a nearly halflower specific surface area 13 and $11 \mathrm{~m}^{2} \mathrm{~g}^{-1}$, whereas the sorted circles only $8 \mathrm{~m}^{2} \mathrm{~g}^{-1}$ for both layers. Such low values of specific surface area are characteristic for materials with a small content of the montmorillonite clay mineral type.

The total grain size distribution (primary and skeleton grains) of the investigated polar soils derived on the different micro-relief forms are presented in Fig. 3.The characteristics of total grain size distribution shows great differentiation not only in the micro-relief forms but also in the depth of the soil profiles. The quantity of skeleton parts $(>2 \mathrm{~mm})$ in the $0-5 \mathrm{~cm}$ layer is the highest in mud boils $32 \%, 29 \%$ in the sorted circles, $26 \%$ in the cell forms, and the lowest $18 \%$ in the tundra polygons. The $10-15 \mathrm{~cm}$ layer is characterized by $30 \%$ of skeleton parts for the cell forms, $21 \%$ for the sorted circles and mud boils, respectively, and $18 \%$ for the tundra polygons, ie the same value as for the higher layer. Therefore, the maximal differences in the quantity of the skeleton parts equal 13 and $12 \%$ for both layers, respectively. Greater differences can be observed in the quantity of primary grain parts for sand $(0.02-2 \mathrm{~mm})$ and silt $(0.002-0.02 \mathrm{~mm})$, and much less for clay $(<0.002 \mathrm{~mm})$. For sand in the $0-5 \mathrm{~cm}$ layer, they are $52 \%$ between the tundra polygons and mud boils, whereas they reach $47 \%$ for the same micro-relief forms in the $10-15$ $\mathrm{cm}$ layer. These differences are slightly lower for silt, $33 \%$ between the mud boils and tundra polygons in the $0-5 \mathrm{~cm}$ layer and $40 \%$ for the same micro-relief forms in the deeper layer. The quantity of clay parts is the lowest and the same for both layers $8 \%$ in the mud boils, $4 \%$ in the cell forms, $3 \%$ in the sorted circle, and $0 \%$ in the tundra polygons. The grain size distributions for both depths and data presented in the paper by Melke et al. (2013) show that the tundra

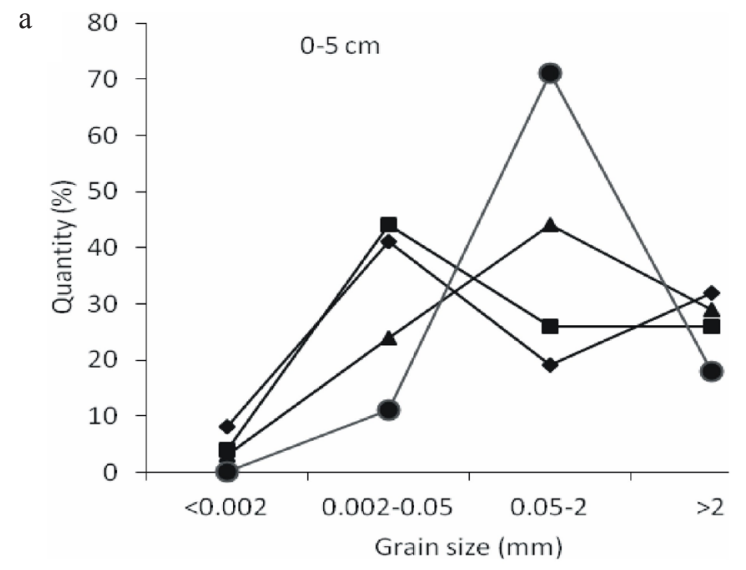

polygons are mainly built of coarser sand grains $(>0.5 \mathrm{~mm})$ and skeleton parts $(>2 \mathrm{~mm})$ more than $80 \%$. The sorted circles show the highest quantity of coarser and medium sand grains $(>0.25 \mathrm{~mm})$ and skeleton parts $(>2 \mathrm{~mm})$. The different texture characterizes the mud boils and cell forms. They contain the highest quantity of silt grains, especially the coarse silt fraction $(0.005-0.02 \mathrm{~mm})$.

The quantity of different size pores in the investigated media is presented in Fig. 4. Pore size distribution shows that the highest quantity of the largest pores $($ dia $>50 \mu \mathrm{m})$ was observed at both depths for the tundra polygons, $17.7 \%$ at $0-5 \mathrm{~cm}$ and $16.9 \%$ at $10-15 \mathrm{~cm}$, whereas the lowest quantity for the cell forms were 5.0 and $5.7 \%$ and for the sorted circles 5.3 and $5.1 \%$, respectively to the depths. The mud boils had 6.5 and $7.0 \%$ pores of this size. The quantity of $50-18.5 \mu \mathrm{m}$ size pores was the lowest of all of them. There were of 9.9 and $8.1 \%$ in the tundra polygons, and between 3.1 and $1.4 \%$ in the other micro-relief forms. The border values of 18.5-3 $5 \mu \mathrm{m}$ size pores were 6.3 and $2.9 \%$ for all investigated soils. The quantity of the smallest pores $(<3 \mu \mathrm{m})$ in which water movement occurs with difficulty was the highest in all the micro-relief forms. It amounted to 26.8 and $24.1 \%$ for the mud boils, 21.7 and $19.8 \%$ for the cell forms, 17.1 and $18.1 \%$ for the tundra polygons, and the lowest 12.6 and $11.7 \%$ for the sorted circles, respectively to the depths.

The analysis of the results obtained (Figs 2-4) allows a statement that water conductivity in polar soils derived on the different micro-relief forms is dependent on pore size distribution, which is strongly connected with the grain size distribution. Comparison of the water conductivity coefficient and the quantity of different size pores in the investigated soils has shown their highest values for the tundra polygons the micro-relief form with the greatest quantity of very large and large pores $(>18.5 \mu \mathrm{m})$, in which water moves under the gravity force or under low capillary forces. A low number of medium and small pores

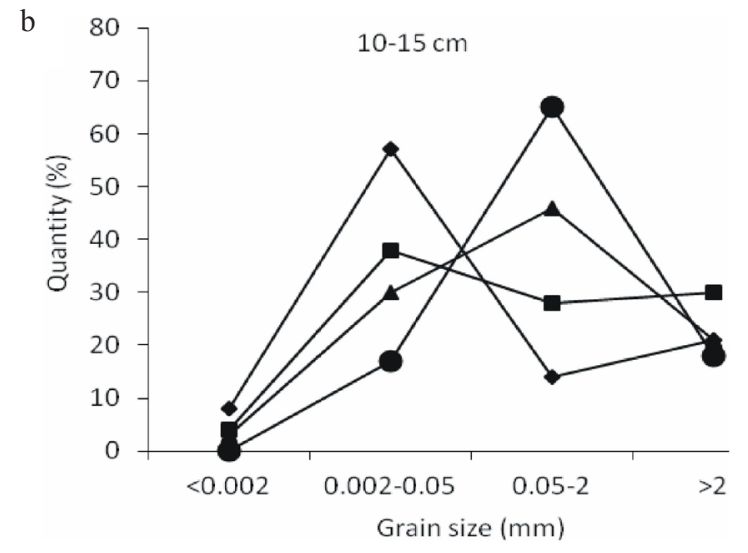

Fig. 3. Total grain size distribution of the investigated polar soils: $\mathrm{a}-0-5 \mathrm{~cm}$ and $\mathrm{b}-10-15 \mathrm{~cm}$ layers. Explanations as in Fig. 2. 


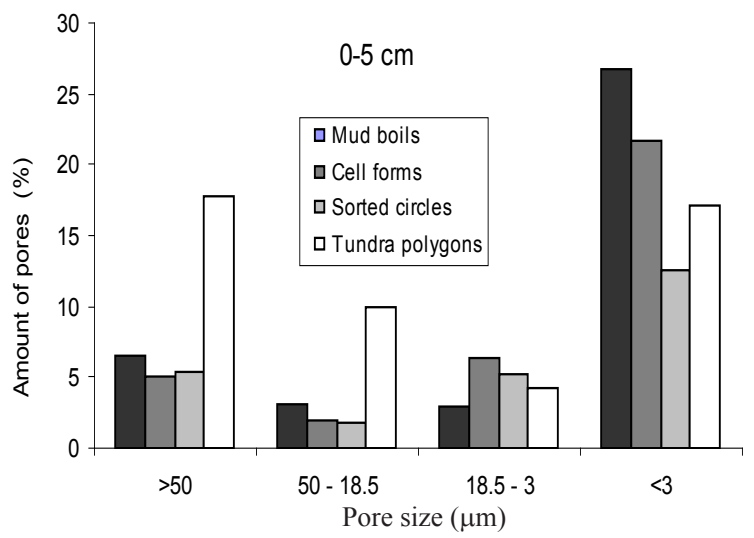

b

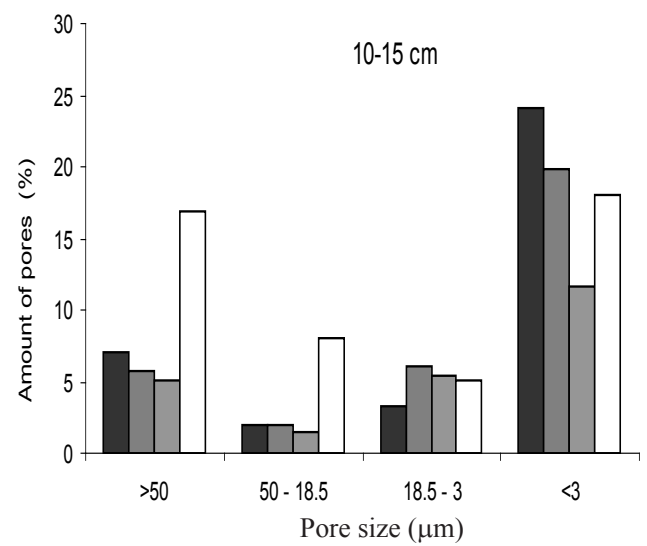

Fig. 4. Amount of different size pores in the investigated polar soils: $\mathrm{a}-0-5 \mathrm{~cm}$ and $\mathrm{b}-10-15 \mathrm{~cm}$ layers.

$(<18.5 \mu \mathrm{m})$ cause a rapid decrease in water movement in soils, which results in the lowest values of water conductivity in this micro-relief form. The similar course of curves for the mud boils, cell forms, and sorted circles is caused by their nearly the same content of very large and large pores. The small, but clear, differences in the quantity of medium and small pores in these soils however show differentiation of water conductivity for soil water potential lower than $-7 \mathrm{~kJ} \mathrm{~m}^{-3}$. The drying process ie removal of water excess, especially during ice and snow thawing, in all the investigated polar soils is satisfied, because the values of water conductivity are high in comparison with, for example, arable soils. This can be seen very clearly especially in the $0-5 \mathrm{~cm}$ layer of all the micro-relief forms.

\section{CONCLUSIONS}

1. Brunic-Turbic Cryosol (Arenic) formed in the tundra polygons shows the greatest water conductivity at the depth of $0-5 \mathrm{~cm}$ for the higher values of water potentials $(-0.1$ to $-7 \mathrm{~kJ} \mathrm{~m}^{-3}$ ) whereas the lowest values are reported for Turbic Cryosol (Skeletic) from the sorted circles. Between -16 and $-100 \mathrm{~kJ} \mathrm{~m}^{-3}$, the values of water conductivity for the tundra polygons rapidly decrease whereas their decrease for the other forms is much lower.

2. In the $10-15 \mathrm{~cm}$ layer for the higher values of water potentials, the shape of water conductivity curves is nearly the same as for the upper soil layer. Likewise in the upper layer, water conductivity is the highest for the tundra polygons. At the lowest potential, water conductivity is the highest for the sorted circles and the lowest in the tundra polygons.

3. The highest quantity of the largest pores was observed at both depths for Brunic-Turbic Cryosols (Arenic) formed in the tundra polygons whereas the lowest ones - for Turbic Cryosols (Siltic, Skeletic) in the cell forms and for Turbic Cryosols (Skeletic) in the sorted circles. The Turbic Cryosols (Siltic, Skeletic) formed in the mud boils show nearly $7 \%$ pores of this size. The quantity of $50-18.5 \mu \mathrm{m}$ size pores was the lowest of all of them. The border values of $18.5-3 \mu \mathrm{m}$ size pores were from 6 to $3 \%$ for all the investigated soils. The quantity of the smallest pores $(>3 \mu \mathrm{m})$ was the highest in all the micro-relief forms (25-12\%).

\section{REFERENCES}

Angiel M., 1994. Heat flux in selected polar soil in spring and summer (Hornsund, Spitsbergen). Polish Polar Res., 15, $51-70$.

Bockheim J.G., 1980. Properties and classification of some soils in coarse textured glacial drift in the Arctic and Antarctic. Geoderma, 24, 45-49.

Chojnicki B.H., 2013. Spectral estimation of wetland carbon dioxide exchange. Int. Agrophys., 27, 1-14.

Fischer Z. and Skiba S., 1993. Some remarks about bioenergetic aspects of tundra soil. Polish Polar Res., 14, 345-355.

Hillel D., 1998. Environmental Soil Physics. Academic Press, San Diego-London-Toronto.

IUSS Working Group WRB, 2007. World Reference Base for Soil Resources-2006 (first update-2007). World Soil Resources Reports, No. 103, FAO Press, Rome, Italy.

Jahn R., Blume H.P., Asio V.B., Spaargaren O., and Schad P., 2006. Guidelines for Soil Description. FAO-ISRIC Press, Rome, Italy.

Kabala C. and Zapart J., 2012. Initial soil development and carbon accumulation on moraines of the rapidly retreating Werenskiold Glacier, SW Spitsbergen, Svalbard archipelago. Geoderma, 175-176, 9-20.

Kirkham M.B., 2014. Principles of Soil And Plant Water Relation. Elsevier, Amsterdam-New York-Londyn-Toronto.

Klimowicz Z., Chodorowski J., Melke J., Uziak S., and Bartmiński P., 2013. Soils. In: Geographical Environment of NW Part of Wedel Jarlsberg Land (Spitsbergen, Svalbard) (Eds P. Zagórski, M. Harasimiuk, J. Rodzik). UMCS Press, Lublin, Poland.

Kutilek M., 2011. Pore size distribution. In: Encyclopedia of Agrophysics (Eds J. Gliński, J. Horabik, J. Lipiec). Springer Press, Dordrecht-Heidelberg-London-New-York.

Kutilek M. and Nielsen D.R., 2010. Facts About Global Warming. Catena Press, Reiskirchen, Germany. 
Lal R. and Shukla M.K., 2004. Principles of Soil Physics. Dekker Press, New York - Basel.

Melke J., Witkowska-Walczak B., and Bartmiński P., 2013. Water retention of arctic zone soils (Spitsbergen). Int. Agrophys., 27, 439-444.

Migała K., Wojtuń B., Szymański W., and Muskała P., 2014. Soil moisture and temperature variation under different types of tundra vegetation during the growing season: A case study from the Fuglebekken catchment, SW Spitsbergen. Catena, 116, 10-18.

Novak V., 2011. Evapotranspiration. In: Encyclopedia of Agrophysics (Eds J. Gliński, J. Horabik, J. Lipiec). Springer Press, Dordrecht-Heidelberg-London-New York.

Paltineau C., Chitu E., and Mateescu E., 2012. New trends for evaporation and climatic water deficit. Int. Agrophys., 26, 159-166.

Ryżak M. and Bieganowski A., 2013. Methodological aspects of determining soil particle-size distribution using the laser diffiraction method. J. Plant Nutr. Soil Sci.,174, 624-633.

Shein E.V. and Gonczarov W.M., 2007. Agrophysics (in Russian). Feniks Press, Rostov, Russia.

Slawiński C., 2003. Influence of soil solid phase parameters on values of hydraulic conducitivity coefficient (in Polish). Acta Agrophysica, 90, 5-75.

Sławiński C., Sobczuk H., Stoffregen H., Walczak R., and Wessolek G., 2002. Effect of data resolution on soil hydraulic conductivity prediction. J. Plant Nutr. Soil Sci., $165,45-49$.

Sławiński C., Walczak R.T., and Skierucha W., 2006. Error analysis of water conductivity coefficient measurement by instantaneous profile method. Int. Agrophysics, 20, 55-61.

Sławiński C., Witkowska-Walczak B., and Walczak R., 2004. Determination of Hydraulic Conductivity in Soil Porous Media. IA PAS Press, Lublin, Poland.

Sobczuk H., Plagge R., Walczak R., and Roth C., 1992. Laboratory equipment and calculation procedures to rapid- ly determine effect of hysteresis on soil hydrophysical properties under nonstationary conditions. Z. Pflanz. Bodenk., 155, 157-163.

Świtoniak M., Melke J., and Bartmiński P., 2014. The differences in cellulolytic activity of arctic soils of Calypsostranda, Spitsbergen. Polar Record, 2, 199-208.

Tedrow J.F.C., 1977. Soils of the Polar Landscape. Rutgers Univ. Press, New Brunswick, NJ, USA.

Trenberth K.E., Jones P.D., Ambenje P., Borariu R., Easterling D., Klein Tank A., Parker D., Rahimzadeh F., Renwick J.A., Rusticucci M., Soden B., and Zhai P., 2007. Observations: surface and atmospheric climate change. In: IPCC Climate Change, the Physical Science Basis, EU Press, Brussels, Belgium.

Van Genuchten M.Th. and Pachepsky Y., 2011. Hydraulic properties of unsaturated soils. In: Encyclopedia of Agrophysics (Eds J. Gliński, J. Horabik, J. Lipiec). Springer Press, Dordrecht-Heidelberg-London-New York.

Washburn A.L., 1980. Geocryology. Wiley Press, New York, USA.

Witkowska-Walczak B., Gliński J., and Slawiński C., 2012. Hydrophysical Properties of Soils. Polish Academy of Sciences Press, Lublin, Poland.

Witkowska-Walczak B. and Sławiński C., 2005. Unsaturated water conductivity and diffusivity in soil aggregates. Polish J. Soil Sci., 37(1), 11-22.

Youngs E.G., 2008. Steady water flow through unsaturated aggregated porous materials. Transp. Porous Media, 71, 147-159.

Zadeh G.E. and Bayat H., 2012. Pedotransfer functions capacibility to simulate behaviour of cmectic soils in estimation of various soil water retention curves. Polish J. Soil Sci., 45(2), 105-128.

Zagórski P., Gajek G., Demczuk P., 2012. The influence of glacier systems of polar catchments on functioning of the coastal zone (Recherchefjorden, Svalbard). Zeitschrift für Geomorphologie, 56, 101-122. 